\begin{tabular}{cc|c}
\hline Tar. Bil. Der. & Journal of Agricultural Sciences \\
& $\begin{array}{c}\text { Dergi web sayfası: } \\
\text { www.agri.ankara.edu.tr/dergi }\end{array}$ & Journal homepage: \\
& www.agri.ankara.edu.tr/journal
\end{tabular}

\title{
Variation in Hay Yield and Quality of New Triticale Lines
}

\author{
Mahmut KAPLAN ${ }^{a}$, Mehmet Fatih YILMAZ ${ }^{\text {b }}$, Rukiye KARA ${ }^{\text {b }}$

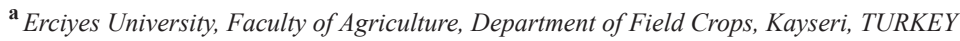 \\ ${ }^{b}$ Kahramanmaraş Agricultural Research Institute, Kahramanmaraş, TURKEY
}

\section{ARTICLE INFO}

Research Article

DOI: $10.15832 /$ tbd. 24602

Corresponding Author: Mahmut KAPLAN, E-mail: mahmutkaplan5@hotmail.com, Tel: +90 (537) 9509538

Received: 24 December 2013, Received in Revised Form: 14 April 2014, Accepted: 22 April 2014

\begin{abstract}
Objectives of the present study are to determine the variations in forage yield and quality of new triticale lines developed by cross-breeding methods and to develop better lines with superior characteristics over the current ones. Experiments were carried out in randomized complete block design with 3 replications during the cropping years of 2011-2012 and 2012-2013. A total of 5 cultivar and 20 lines were used as the plant material of the experiments. Genotypes were harvested at milk stage and their herbage yield, hay yield, crude protein yield and chemical composition were investigated. Twoyears average results revealed that herbage yields varied between 36.44-48.47 $\mathrm{t} \mathrm{ha}^{-1}$, hay yields between 12.77-18.68 $\mathrm{t} \mathrm{ha}^{-1}$, crude protein yields between 1.02-1.80 $\mathrm{t} \mathrm{ha}^{-1}$, acid detergent fiber (ADF) between 32.92-44.63\%, neutral detergent fiber (NDF) between 63.72-78.47\%, crude ash ratios between 5.06-7.87\%, crude protein content between $6.21-11.36 \%$, dry matter digestibility (DDM) between 54.14-63.25\%, dry matter intake (DMI) between 1.528-1.881 and relative feed value (RFV) between 64.18-89.31. Current results revealed superior characteristics for new triticale genotypes developed with cross-breeding over the current standard lines with regard to investigated parameters. It was concluded that cross-breeding yielded positive outcomes and therefore, currently investigated high-yield and quality lines should be prepared for registration.
\end{abstract}

Keywords: Triticale; New lines; Hay yield; Chemical composition; Relative feed value

\section{Yeni Tritikale Hatlarında Ot Verim ve Kalite Özelliklerinde Varyasyon}

\section{ESER BİLGISI}

Araștırma Makalesi

Sorumlu Yazar: Mahmut KAPLAN, E-posta: mahmutkaplan5@hotmail.com, Tel: +90 (537) 9509538

Geliş Tarihi: 24 Aralık 2013, Düzeltmelerin Gelişi: 14 Nisan 2014, Kabul:22 Nisan 2014

\section{ÖZET}

Çalışmanın amacı yeni melez tritikale hatlarının ot verimi ve ot kalitesi yönünden varyasyonu belirlemektir. Deneme 2011-2012 ve 2012-2013 yıllarında 2 yıl süre ile tesadüf blokları deneme desenine göre 3 tekrarlamalı olarak kurulmuş ve analiz edilmiştir. Araştırmada 5 çeşit ve 20 hat kullanılmıştır. Bitkiler süt olum döneminde hasat edilmiştir. Araştırmada yeşil ot verimi, kuru ot verimi, ham protein verimi, ham protein oranı, ADF, NDF ve ham kül oranı incelenmiştir. İki yıllık araştırma sonuçlarının ortalamasına göre; yeşil ot verimi 36.44-48.47 t ha-1, kuru ot verimi 12.77-18.68 $\mathrm{t} \mathrm{ha}^{-1}$, 
protein verimi 1.02-1.80 $\mathrm{t} \mathrm{ha}^{-1}$, asitte çözünmeyen lif (ADF) oranı \% 32.92-44.63, nötrde çözünmeyen lif (NDF) oranı $\%$ 63.72-78.47, ham kül oranı \% 5.06-7.87, ham protein oranı \% 6.21-11.36, sindirilebilir kuru madde (SKM) \% 54.1463.25, kuru madde tüketimi (KMT) 1.528-1.881 ve nispi yem değeri (NYD) 64.18-89.31 arasında değişmiştir. Araştırma sonuçlarına göre; melezleme ile elde edilen yeni tritikale genotiplerinin incelenen özellikler yönünden değerleri standart çeşitlerden daha yüksek olmuştur. Yapılan melezleme sonuçlarının olumlu neticeler verdiği ve bu hatların ot verimi ve kalitesi yönünden tescil için hazırlanması gerektiği düşünülmektedir.

Anahtar Kelimeler: Tritikale; Yeni hatlar; Kuru ot verimi; Kimyasal kompozisyon; Nispi yem değeri

(C) Ankara Üniversitesi Ziraat Fakültesi

\section{Introduction}

Cool season cereals like oat, barley, wheat, rye and triticale are usually grazed during tillering period or commonly harvested as forage source for livestock (Uncuer 2011). Triticale is the cross-breed of wheat and rye and used both for kernel and herbage yields (Iğne et al 2007). While triticale provides at least $20 \%$ more hay yield than wheat, forage quality is also better than wheat and rye (Koch \& Paisley 2002; Mut et al 2006). Triticale is also a good feed source for livestock because of its high protein yield and amino acid balance.

Breeding materials are usually evaluated with regard to yield characteristics, resistance against biotic and abiotic stress conditions and forage quality parameters. Forage quality is commonly evaluated by Relative Feed Value criteria developed in the USA for alfalfa and other coarse fodder (Rohweder et al 1978; Ball et al 1996; Bozkurt 2011). Such quality varies based on crop species, harvest or grazing durations, cultural practices and climate parameters. Besides, livestock productivity depends on the amount of feed consumed by the animals, availability and digestibility of the feed (Van Soest 1982; McDonald et al 1995; Lekgari et al 2008). In present study, variations in forage yields and quality of some triticale lines developed by crossbreeding methods were investigated and better lines with superior characteristics over the current registered ones were tried to be developed. This will be the first study in Turkey investigating forage yield and quality parameters of triticale lines.

\section{Material and Methods}

Experiments were carried out over the research fields of Eastern Mediterranean Transition Zone Agricultural Research Center during the cropping years of 2011-12 and 2012 -13. The genotypes used in experiments are provided in Table 1.

The research province, Kahramanmaraş is located in Eastern-Mediterranean Region between $37^{\circ} 38^{\prime}$ 'North latitudes and $36^{\circ} 37^{\prime}$ 'East longitudes and has an altitude of $568 \mathrm{~m}$. Mediterranean climate is dominant in the province and day-night temperature difference is low. Climate parameters for research site are provided in Table 2 (TSMS 2012; TSMS 2013).

While the long-term average precipitation of the experimental site is $669.1 \mathrm{~mm}$, annual total precipitations of the experimental years 2011-12 and 2012-13 respectively realized as 756.8 and $583.1 \mathrm{~mm}$. The first cropping year had $87.7 \mathrm{~mm}$ higher precipitation and the second year had 86 $\mathrm{mm}$ lower precipitation than the long-term average. Beside the amount, distribution of the precipitation within the year also significantly varied between the years. Especially, the amount of precipitation during the germination, emergence and initial growth period of the second year (November-December) were relatively lower than the long-term average. The amount of precipitations during January and February of the first year were significantly higher than that of the second year and long-term average (Table 2). On the other hand, the amount of precipitations during plant generative development periods (booting, spiking, flowering) covering the months March and April of both years were below the long-term average. Long-term annual average 
temperature of Kahramanmaraş Province is $12.6{ }^{\circ} \mathrm{C}$. Annual average temperatures of the experimental years respectively realized as 12.5 and $14.0{ }^{\circ} \mathrm{C}$. Temperature in April of the first year was higher and the temperature in May was lower than the second year and long-term average. Annual average relative humidity of the province is $62.0 \%$ and the relative humidity of the experimental years respectively realized as 57.2 and $61.9 \%$.

The soil texture is loamy with a soil $\mathrm{pH}$ of 7.61 in the first year and 8.00 in the second year. Lime contents were respectively observed as $12.55 \%$ and $24.59 \%$. Available phosphorus varied between $0.046-0.080 \mathrm{t} \mathrm{ha}^{-1}$, available potassium between $0.459-1.270 \mathrm{tha}^{-1}$. Organic matter contents of the soils varied between $1.22-0.97$.
Experiments were carried out in randomized complete block design with 3 replications. Seeding rate was 500 seeds $\mathrm{m}^{-2}$ and seeding was performed with a plot-drill over $6 \times 1.5 \mathrm{~m}$ size plots. There were 6 rows in each plot with row spacing of 20

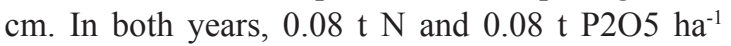
were applied to soil during sowings and additional $0.1 \mathrm{t} \mathrm{ha}^{-1} \mathrm{~N}$ was supplied during tillering period. Irrigation was not performed in both years and herbicide (Grand Star) was used for broad-leaf weeds. Plants were harvested at milk-stage. Side rows and $1 \mathrm{~m}$ strips at top and bottom of the plots were omitted as side effects. A total of $500 \mathrm{~g}$ fresh sample was taken from harvested plants and dried at $70{ }^{\circ} \mathrm{C}$ for 48 hours. Then, dry matter ratios and hay yields were determined.

\section{Table 1- Pedigrees for triticale lines}

\section{Çizelge 1-Tritikale hatlarına ait pedigriler}

\begin{tabular}{|c|c|}
\hline Genotypes & Genotype pedigrees \\
\hline Line 1 & Mikham-2002 / 01-02 Stbvd-21 \\
\hline Line 2 & Cimmyt-3 / Anoas_3/Tatu_4//Susi_2 \\
\hline Line 3 & 431_Tu_1-11/3/Dargo/Ibex//Civet\#2/Karma \\
\hline Line 4 & $\begin{array}{l}\text { Samur Sortu / 01-02 Stbvd-19 } \\
\text { Tatlicak-97 }\end{array}$ \\
\hline Line 6 & Cimmyt-3 / Karma \\
\hline Line 7 & 01-02 Ktbvd-1/ Karma \\
\hline Line 8 & 23Fahat5/Pollmer3ctss/Pollmer_3/Foca_2-1 \\
\hline Line 9 & $\begin{array}{l}\text { 23Fahat5/Pollmer3ctss/Pollmer_3/Foca_2-1 } \\
\text { Melez-2001 }\end{array}$ \\
\hline Line 11 & 23Fahat5/Pollmer3ctss/Pollmer_3/Foca_2-1 \\
\hline Line 12 & Bagal_3/Faras_1/3/Ardi_1/Topo1419//Erizo_9/Karma \\
\hline Line 13 & Fahad_8-2*2//Ptr/Pnd-T/3/Erizo_11//Yogui_3/Pollmer_3/Foca_2-1 \\
\hline Line 14 & $\begin{array}{l}\text { Ct179.80/3/150.83//2*Tesmo_1musx603/01-02ktvd-17 } \\
\text { Mikham-2002 }\end{array}$ \\
\hline Line 16 & Cimmyt-3 / Anoas_3/Tatu_4//Susi_2 \\
\hline Line 17 & Cimmyt-3 / Karma \\
\hline Line 18 & 23fahat5/Pollmer3ctss/Pollmer_3/Foca_2-1 \\
\hline Line 19 & $\begin{array}{l}\text { Chd1089/Pollmer_2.3.1/Pollmer_3/Foca_2-1 } \\
\text { Alperbey }\end{array}$ \\
\hline Line 21 & Ct179.80/3/150.83//2*Tesmo_1musx603/01-02ktvd-17 \\
\hline Line 22 & Presto 6d(6a)//Bull_10/Manati_1/01-02 Ktvd-32 \\
\hline Line 23 & Bull_10/Manati_1//Faras/Cmh84.4414 \\
\hline Line 24 & $\begin{array}{l}33--1 / 42-2 \\
\text { Karma }\end{array}$ \\
\hline
\end{tabular}


Table 2- Climate parameters for experimental years and long term averages

Çizelge 2-Deneme yılları ve uzun yıllar ortalamasına ait bazı iklim verileri

\begin{tabular}{|c|c|c|c|c|c|c|c|c|c|}
\hline \multirow[b]{2}{*}{ Months } & \multicolumn{3}{|c|}{ Precipitation (mm) } & \multicolumn{3}{|c|}{ Temperature $\left({ }^{\circ} \mathrm{C}\right)$} & \multicolumn{3}{|c|}{ Relative humidity (\%) } \\
\hline & $\begin{array}{l}2011- \\
2012 \\
\end{array}$ & $\begin{array}{l}2012- \\
2013 \\
\end{array}$ & $\begin{array}{l}\text { Long-term } \\
(1975-2011)\end{array}$ & $\begin{array}{l}2011- \\
2012 \\
\end{array}$ & $\begin{array}{l}2012- \\
2013 \\
\end{array}$ & $\begin{array}{l}\text { Long- } \\
\text { term }\end{array}$ & $\begin{array}{l}2011- \\
2012 \\
\end{array}$ & $\begin{array}{l}2012- \\
2013 \\
\end{array}$ & $\begin{array}{l}\text { Long- } \\
\text { term }\end{array}$ \\
\hline November & 93.2 & 36.4 & 90.9 & 8.7 & 13.4 & 11.5 & 60.6 & 70.6 & 64.7 \\
\hline December & 85.2 & 67.6 & 124.4 & 6.3 & 7.7 & 6.6 & 64.7 & 76.4 & 71.3 \\
\hline January & 325.0 & 111.0 & 125.4 & 6.9 & 6.2 & 4.9 & 79.9 & 72.3 & 70.0 \\
\hline February & 199.1 & 131.9 & 112.3 & 4.1 & 8.6 & 6.3 & 61.9 & 74.0 & 66.0 \\
\hline March & 0.0 & 77.5 & 94.8 & 8.6 & 11.3 & 10.6 & 51.8 & 52.1 & 60.5 \\
\hline April & 0.0 & 65.9 & 76.1 & 17.7 & 17.1 & 15.4 & 49.3 & 52.5 & 58.4 \\
\hline May & 41.3 & 76.5 & 39.3 & 19.9 & 22.4 & 20.4 & 55.8 & 53.4 & 54.7 \\
\hline June & 13.0 & 16.3 & 5.9 & 27.9 & 25.4 & 25.2 & 33.4 & 43.9 & 50.7 \\
\hline Total & 756.8 & 583.1 & 669.1 & & & & & & \\
\hline Average & & & & 12.5 & 14.0 & 12.6 & 57.2 & 61.9 & 62.0 \\
\hline
\end{tabular}

Table 3- Physical and chemical characteristics of experimental soils

Çizelge 3- Deneme alanı topraklarının bazı fiziksel ve kimyasal özellikleri

\begin{tabular}{rlccccc}
\hline Years & Texture & $p H$ & $\mathrm{CaCO}_{3}(\%)$ & $\begin{array}{c}\mathrm{P}_{2} \mathrm{O}_{5} \\
\left(t h a^{-1}\right)\end{array}$ & $\begin{array}{c}\mathrm{K}_{2} \mathrm{O} \\
\left(\mathrm{t} \mathrm{ha} a^{-1}\right.\end{array}$ & $\begin{array}{c}\text { Organic matter } \\
(\%)\end{array}$ \\
\hline $2011-12$ & Loamy & 7.61 & 12.55 & 0.046 & 0.459 & 1.22 \\
$2012-13$ & Loamy & 8.00 & 24.59 & 0.080 & 1.270 & 0.97 \\
\hline
\end{tabular}

Hay samples were grinded in a hand-mill with 1 $\mathrm{mm}$ sieve. Crude ash contents of the samples were determined by burning the samples at $550{ }^{\circ} \mathrm{C}$ for 8 hours. Kjeldahl method was used to determine nitrogen $(\mathrm{N})$ contents of dry samples. Crude protein ratios were calculated by using the equation of $\mathrm{N} \mathrm{x}$ 6.25 (AOAC 1990). NDF (Van Soest \& Wine 1967) and ADF (Van Soest 1963) contents were analyzed with an ANKOM 200 Fiber Analyzer (ANKOM Technology Corp. Fairport, NY, USA) device. Dry matter digestibility, dry matter intake and relative feed value (RFV) were calculated by using the following equations (Rohweder et al 1978):

To calculate relative feed value, initially dry mater digestibility (DMD) was calculated from ADF value by;

$$
D M D \%=88.9-(0.779 \times A D F \%)
$$

Dry matter intake (DMI) based on animal liveweight was calculated from NDF value by;

$$
D M I \% \text { of } B W=120 / N D F \%
$$

Then, relative feed value was calculated from DMD and DMI by;

$$
R F V=D D M \% \times D M I \% \times 1.29
$$

Relative feed values were evaluated by using the values provided in standards for hays in Table 4.

Data variance analyses were performed by using SAS (SAS Inst., 1999) statistical software. Duncan's multiple range tests was employed to compare the treatment means. Cluster analysis of 25 triticale lines was performed by using DICE similarity index and UPGMA method and dendrograms were prepared for yield, chemical composition and digestibility parameters. 
Table 4- Relative feed value standards $\mathrm{s}^{\mathrm{a}}$

Çizelge 4- Nispi yem değeri standartlart ${ }^{a}$

\begin{tabular}{ccccc}
\hline Quality standards & $C P$ & $A D F(\%)(D M)$ & $N D F(\%)(D M)$ & $R F V$ \\
\hline The best quality & $>19$ & $<31$ & $<40$ & $>151$ \\
1 & $17-19$ & $31-40$ & $40-46$ & $151-125$ \\
2 & $14-16$ & $36-40$ & $47-53$ & $124-103$ \\
3 & $11-13$ & $41-42$ & $54-60$ & $102-87$ \\
4 & $8-10$ & $43-45$ & $61-65$ & $86-75$ \\
5 & 8.00 & $>45$ & $>65$ & $<75$ \\
\hline
\end{tabular}

${ }^{\text {a }}$, relative feed value is assumed to be 100 when the ADF is $41 \%$ and NDF is $53 \%$ (Rohweder et al 1978)

\section{Results and Discussion}

Herbage, hay and protein yields of triticale genotypes are provided in Table 5. While only the differences between protein yields of the years were not significant, the differences between the entire parameters of the years, genotypes and year $\mathrm{x}$ genotype interactions were found to be significant $(\mathrm{P}<0.01)$. The lowest herbage yield of the first year was observed in line L9 $\left(30.09 \mathrm{t} \mathrm{ha}^{-1}\right)$ and the highest in L19 $\left(49.56 \mathrm{t} \mathrm{ha}^{-1}\right)$. During the second year, the lowest and the highest values were respectively observed in L21 (32.84 $\left.\mathrm{t} \mathrm{ha}^{-1}\right)$ and Melez 2001 (54.69 $\left.\mathrm{t} \mathrm{ha}^{-1}\right)$. With regard to average of years, the lowest herbage yield was obtained from L21 (36.44 $\left.\mathrm{t} \mathrm{ha}^{-1}\right)$ and the highest from L4 $\left(48.47 \mathrm{t} \mathrm{ha}^{-1}\right)$. The lowest hay yields were observed in cultivar Karma with $12.44 \mathrm{t} \mathrm{ha}^{-1}$ in the first year, $13.09 \mathrm{t} \mathrm{ha}^{-1}$ in the second year and $12.77 \mathrm{t} \mathrm{ha}^{-1}$ as the average of years. The highest hay yield was obtained from L19 (21.13 t ha $\left.\mathrm{h}^{-1}\right)$ in the first year and from L8 in the second year and as the average of years (respectively with 20.36 and $18.68 \mathrm{t}^{-} \mathrm{ha}^{-}$ $\left.{ }^{1}\right)$. The lowest crude protein yield was observed in L1 $\left(0.96 \mathrm{t} \mathrm{ha}^{-1}\right)$ in the first year, in L7 $(0.99 \mathrm{t}$ $\left.\mathrm{ha}^{-1}\right)$ in the second year and in L12 (1.02 $\left.\mathrm{t} \mathrm{ha}^{-1}\right)$ as the average of years. The highest crude protein yield of the years and average of the years were all observed in L12 respectively as 1.77, 1.80 and $1.78 \mathrm{tha}^{-1}$.

Chemical composition of the triticale genotypes are provided in Table 6 . The differences between entire chemical composition parameters were found to be significant $(\mathrm{P}<0.01)$. ADF ratios varied between $30.97-46.45 \%$ in 2011 with the lowest ratio in L24 and the highest in L12. The ADF values of the year 2012 varied between $33.48-44.44 \%$ with the lowest value in the cultivar Alperbey and the highest value in L7. With regard to average of years, the lowest value was seen in L24 (32.92\%) and the highest value in L12 $(44.63 \%)$. The NDF ratios of the first year varied between 59.84-79.28\% with the lowest value in L1 and the highest value in L12. During the second year, NDF values varied between $59.52-77.66 \%$ with the lowest ratio in cultivar Karma and the highest ratio in L12. Considering the average of years, the values varied between $63.72-78.47 \%$ with the lowest value in L2 and the highest value in L12. The lowest crude ash ratio of the first year was observed in L18 (4.85\%), the lowest value of the second year in L21 $(4.88 \%)$ and the lowest average of years in L21 (5.06\%). The highest values of the first and second year and the average of years were respectively observed in L9 (8.89\%), L3 (7.82\%) and L9 (7.87\%). Relatively larger differences were observed in crude protein ratios of the triticale genotypes. While L1 yielded the lowest crude protein ratio in both years and average of years, the highest value was obtained from L12 (12.48\%) in the first year, from cultivar Mikam $(10.69 \%)$ and as the average of years from L12 (11.36\%). 


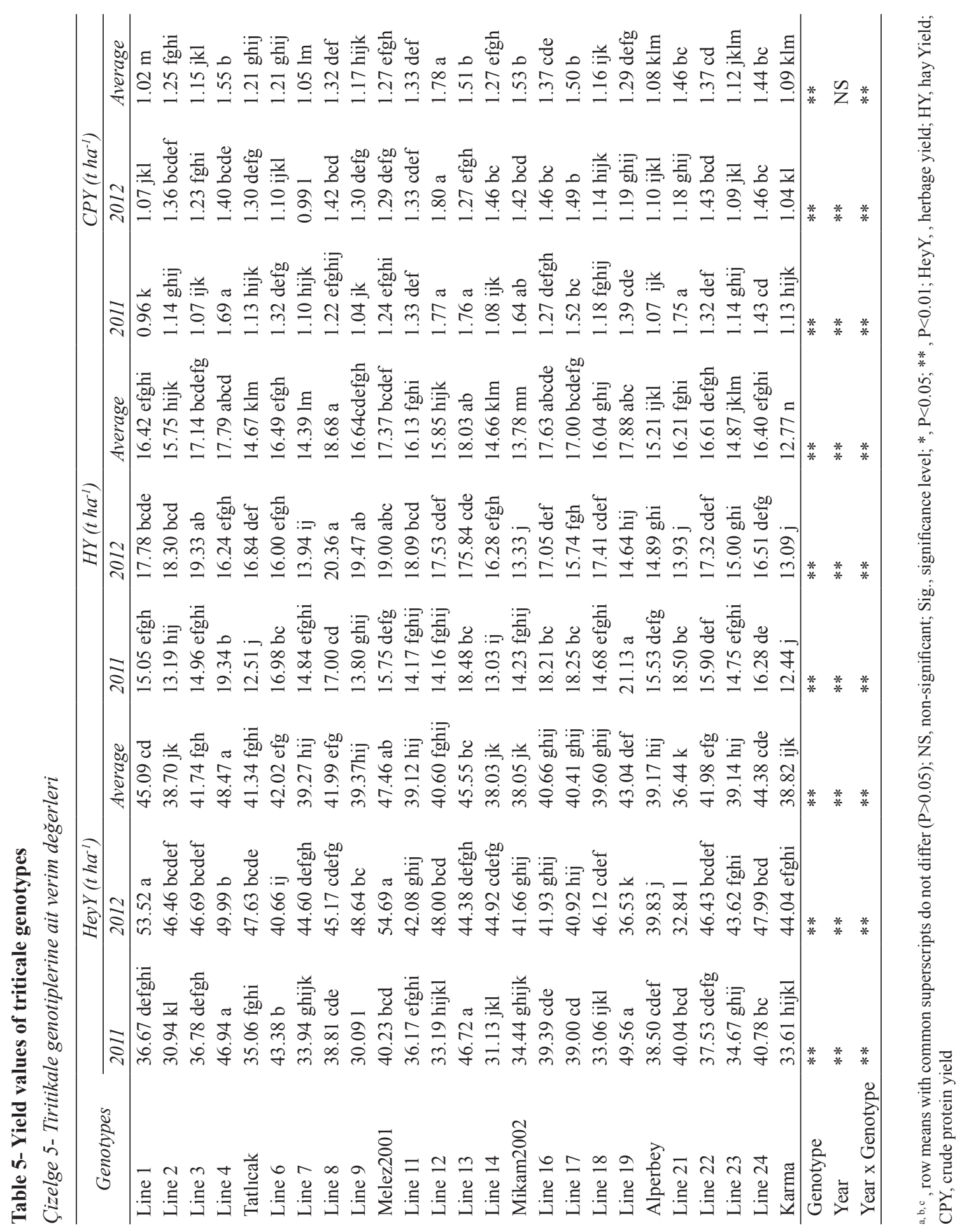

Tarım Bilimleri Dergisi - Journal of Agricultural Sciences 21 (2015) 50-60 


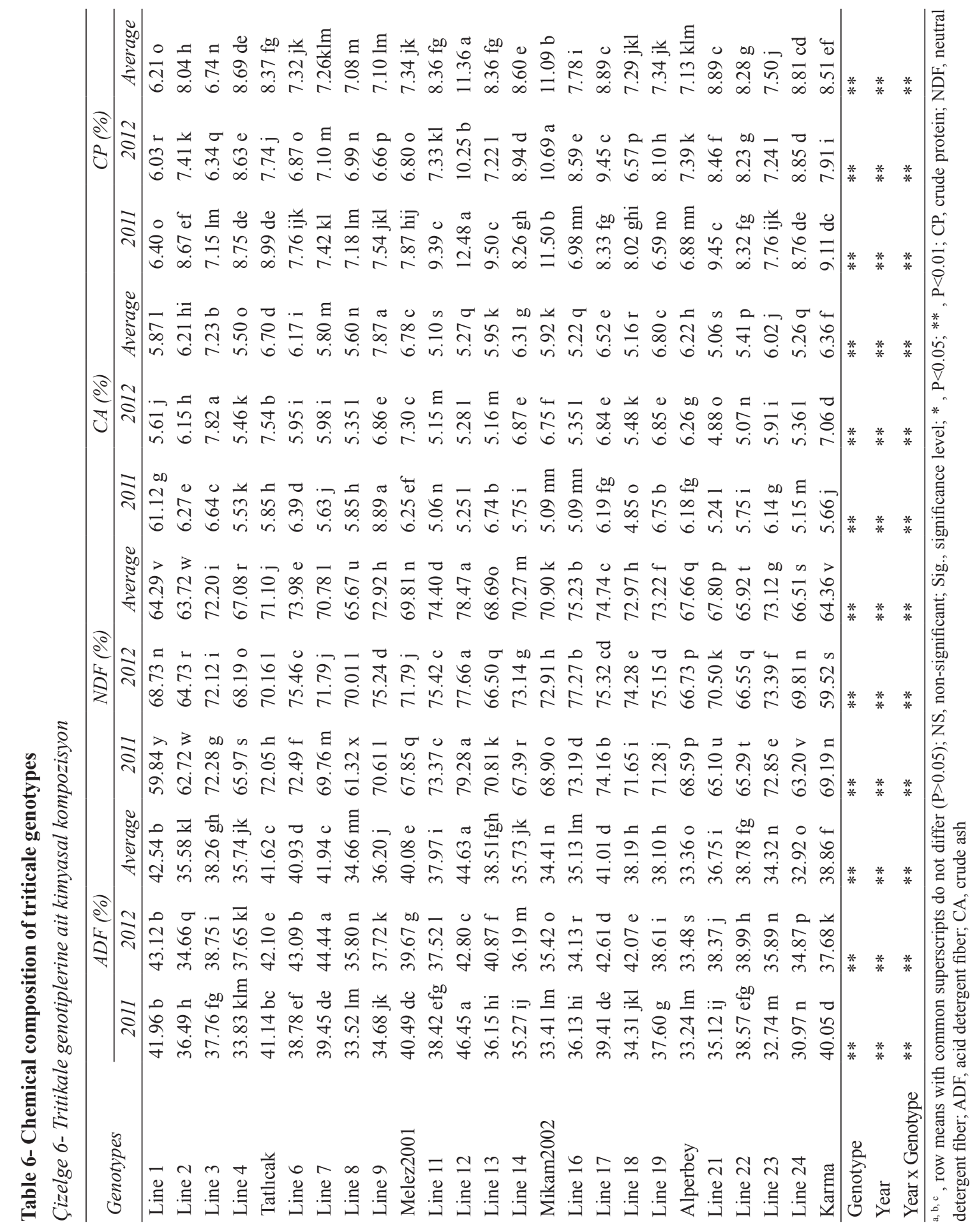


Digestibility parameters of the triticale genotypes are provided in Table 7 . The differences between entire digestibility parameters were found to be significant $(\mathrm{P}<0.01)$. DMD values of the first year varied between $52.71-64.78 \%$ with the lowest value in L12 and the highest value in L24. The values of the second year varied between $54.28-62.82 \%$ with the lowest value in L7 and the highest value in cultivar Alperbey. With regard to average of years, DMD values varied between 54.14 - $63.25 \%$ with the lowest value in L12 and the highest value in L24. The lowest DMI ratios were obtained from line L12 as of $1.510 \%$ in the first year, $1.547 \%$ in the second year and $1.528 \%$ in the average of years. The highest DMI value was observed in L1 (2.006\%) in the first year, in cultivar Karma (2.017\%) in the second year

Table 7- Digestibility of triticale genotypes

Çizelge 7- Tritikale genotiplerine ait sindirilebilirlik değerleri

\begin{tabular}{|c|c|c|c|c|c|c|c|c|c|}
\hline \multirow[b]{2}{*}{ Genotypes } & \multicolumn{3}{|c|}{$D M D(\%)$} & \multicolumn{3}{|c|}{$D M I(\%)$} & \multicolumn{3}{|c|}{$R F V$} \\
\hline & 2011 & 2012 & Average & 2011 & 2012 & Average & 2011 & 2012 & Average \\
\hline Line 1 & $56.21 \mathrm{~m}$ & $55.31 \mathrm{r}$ & $55.76 \mathrm{n}$ & $2.006 \mathrm{a}$ & $1.747 \mathrm{e}$ & $1.876 \mathrm{~b}$ & $87.35 \mathrm{c}$ & 74.831 & $81.09 \mathrm{~g}$ \\
\hline Line 2 & $60.47 \mathrm{~g}$ & $61.90 \mathrm{c}$ & $61.19 \mathrm{de}$ & $1.910 \mathrm{c}$ & $1.853 \mathrm{~b}$ & $1.881 \mathrm{a}$ & $89.67 \mathrm{~b}$ & $88.94 \mathrm{~b}$ & $89.31 \mathrm{a}$ \\
\hline Line 3 & $59.48 \mathrm{hi}$ & $58.71 \mathrm{k}$ & $59.10 \mathrm{hi}$ & $1.660 \mathrm{r}$ & $1.663 \mathrm{i}$ & $1.662 \mathrm{~m}$ & $76.53 \mathrm{j}$ & $75.71 \mathrm{k}$ & 76.121 \\
\hline Line 4 & $62.54 \mathrm{bcd}$ & $59.57 \mathrm{hi}$ & $61.06 \mathrm{ef}$ & $1.820 \mathrm{f}$ & $1.760 \mathrm{~d}$ & $1.790 \mathrm{f}$ & $88.17 \mathrm{c}$ & $81.24 \mathrm{f}$ & $84.71 \mathrm{e}$ \\
\hline Tatlicak & $56.85 \mathrm{~lm}$ & 56.10 o & $56.48 \mathrm{~m}$ & $1.667 \mathrm{q}$ & $1.710 \mathrm{~g}$ & 1.6881 & 73.391 & $74.36 \mathrm{~m}$ & $73.88 n$ \\
\hline Line 6 & $58.69 \mathrm{ij}$ & $55.33 \mathrm{r}$ & 57.011 & $1.657 \mathrm{r}$ & $1.590 \mathrm{o}$ & $1.623 \mathrm{q}$ & $75.30 \mathrm{k}$ & $68.19 \mathrm{r}$ & $71.75 \mathrm{o}$ \\
\hline Line 7 & $58.17 \mathrm{jk}$ & $54.28 \mathrm{~s}$ & $56.23 \mathrm{~m}$ & 1.7201 & $1.670 \mathrm{i}$ & $1.695 \mathrm{k}$ & 77.55 hij & $70.32 \mathrm{p}$ & $73.94 n$ \\
\hline Line 8 & $62.78 \mathrm{bc}$ & $61.02 \mathrm{f}$ & $61.90 \mathrm{bc}$ & $1.957 \mathrm{~b}$ & $1.713 \mathrm{~g}$ & $1.835 \mathrm{c}$ & $95.22 \mathrm{a}$ & $81.05 \mathrm{f}$ & $88.13 \mathrm{~b}$ \\
\hline Line 9 & $61.89 \mathrm{de}$ & $59.51 \mathrm{i}$ & $60.70 \mathrm{f}$ & $1.700 \mathrm{~m}$ & $1.593 \mathrm{o}$ & $1.647 \mathrm{n}$ & $81.51 \mathrm{f}$ & $73.57 n$ & $77.54 \mathrm{j}$ \\
\hline Melez2001 & $57.36 \mathrm{kl}$ & $57.99 \mathrm{~m}$ & $57.68 \mathrm{k}$ & $1.770 \mathrm{~h}$ & $1.670 \mathrm{i}$ & $1.720 \mathrm{i}$ & $78.62 \mathrm{~h}$ & 75.121 & $76.87 \mathrm{k}$ \\
\hline Line 11 & 58.97 hij & $59.67 \mathrm{~h}$ & $59.32 \mathrm{~h}$ & $1.637 \mathrm{t}$ & $1.590 \mathrm{o}$ & $1.613 \mathrm{r}$ & $74.74 \mathrm{k}$ & $73.58 \mathrm{n}$ & $74.16 \mathrm{n}$ \\
\hline Line 12 & $52.71 \mathrm{n}$ & $55.56 \mathrm{q}$ & $54.14 \mathrm{o}$ & $1.510 \mathrm{v}$ & $1.547 \mathrm{p}$ & $1.528 \mathrm{u}$ & $61.84 \mathrm{~m}$ & $66.53 \mathrm{~s}$ & $64.18 \mathrm{q}$ \\
\hline Line 13 & $60.74 \mathrm{fg}$ & $57.07 \mathrm{n}$ & $58.91 \mathrm{hij}$ & $1.693 n$ & $1.803 \mathrm{c}$ & $1.748 \mathrm{~h}$ & $79.77 \mathrm{~g}$ & $79.80 \mathrm{~g}$ & $79.79 \mathrm{~h}$ \\
\hline Line 14 & 61.43 ef & $60.71 \mathrm{~g}$ & 61.07 ef & $1.780 \mathrm{~g}$ & $1.640 \mathrm{k}$ & $1.710 \mathrm{j}$ & $84.77 \mathrm{de}$ & $77.20 \mathrm{j}$ & $80.98 \mathrm{~g}$ \\
\hline Mikam2002 & $62.87 \mathrm{bc}$ & $61.31 \mathrm{e}$ & $62.09 \mathrm{~b}$ & $1.740 \mathrm{j}$ & $1.647 \mathrm{j}$ & $1.693 \mathrm{k}$ & $84.87 \mathrm{de}$ & $78.21 \mathrm{~h}$ & $81.54 \mathrm{~g}$ \\
\hline Line 16 & $60.75 \mathrm{fg}$ & $62.31 \mathrm{~b}$ & $61.53 \mathrm{~cd}$ & $1.640 \mathrm{t}$ & $1.550 \mathrm{p}$ & $1.595 \mathrm{t}$ & $77.20 \mathrm{ij}$ & 75.001 & 76.101 \\
\hline Line 17 & $58.20 \mathrm{jk}$ & $55.71 \mathrm{p}$ & 56.961 & $1.620 \mathrm{u}$ & $1.590 \mathrm{o}$ & $1.605 \mathrm{~s}$ & 72.991 & $68.78 \mathrm{q}$ & $70.89 \mathrm{p}$ \\
\hline Line 18 & $62.17 \mathrm{cde}$ & 56.13 o & $59.15 \mathrm{~h}$ & $1.673 \mathrm{p}$ & $1.617 \mathrm{~m}$ & 1.645 no & $80.69 \mathrm{fg}$ & $70.27 \mathrm{p}$ & $75.48 \mathrm{~m}$ \\
\hline Line 19 & $59.61 \mathrm{~h}$ & $58.82 \mathrm{k}$ & $59.22 \mathrm{~h}$ & $1.680 \mathrm{o}$ & $1.600 \mathrm{n}$ & $1.640 \mathrm{p}$ & 77.78 hi & 72.79 o & $75.29 \mathrm{~m}$ \\
\hline Alperbey & $63.01 \mathrm{bc}$ & $62.82 \mathrm{a}$ & $62.92 \mathrm{a}$ & $1.750 \mathrm{i}$ & $1.797 \mathrm{c}$ & $1.773 \mathrm{~g}$ & $85.43 \mathrm{~d}$ & $87.55 \mathrm{c}$ & $86.49 \mathrm{c}$ \\
\hline Line 21 & 61.54 ef & $59.01 \mathrm{j}$ & $60.28 \mathrm{~g}$ & $1.843 \mathrm{e}$ & $1.700 \mathrm{~h}$ & $1.772 \mathrm{~g}$ & $87.92 \mathrm{c}$ & $77.84 \mathrm{i}$ & $82.88 \mathrm{f}$ \\
\hline Line 22 & 58.86 hij & 58.521 & $58.69 \mathrm{ij}$ & $1.840 \mathrm{e}$ & $1.800 \mathrm{c}$ & $1.820 \mathrm{~d}$ & $83.83 \mathrm{e}$ & $81.79 \mathrm{e}$ & $82.81 \mathrm{f}$ \\
\hline Line 23 & $63.40 \mathrm{~b}$ & $60.94 \mathrm{f}$ & $62.17 \mathrm{~b}$ & $1.650 \mathrm{~s}$ & 1.6331 & $1.642 \mathrm{op}$ & $80.93 \mathrm{f}$ & $77.22 \mathrm{j}$ & 79.081 \\
\hline Line 24 & $64.78 \mathrm{a}$ & $61.73 \mathrm{~d}$ & $63.25 \mathrm{a}$ & $1.900 \mathrm{~d}$ & $1.720 \mathrm{f}$ & $1.810 \mathrm{e}$ & $95.32 \mathrm{a}$ & $82.23 \mathrm{~d}$ & 88.78 a \\
\hline Karma & $57.70 \mathrm{k}$ & $59.55 \mathrm{hi}$ & $58.63 \mathrm{j}$ & $1.733 \mathrm{k}$ & $2.017 \mathrm{a}$ & $1.875 \mathrm{~b}$ & 77.56 hij & $93.04 \mathrm{a}$ & $85.30 \mathrm{~d}$ \\
\hline Genotype & $* *$ & $* *$ & $* *$ & $* *$ & $* *$ & $* *$ & $* *$ & $* *$ & $* *$ \\
\hline Year & $* *$ & $* *$ & $* *$ & $* *$ & $* *$ & $* *$ & $* *$ & $* *$ & $* *$ \\
\hline Year x Genotype & $* *$ & $* *$ & $* *$ & $* *$ & $* *$ & $* *$ & $* *$ & $* *$ & $* *$ \\
\hline
\end{tabular}

a, b, c , row means with common superscripts do not differ ( $\mathrm{P}>0.05)$; NS, non-significant; Sig., significance level; *, $\mathrm{P}<0.05 ; * *$, $<0.01$; DMD, dry matter digestibility; DMI, dry matter intake; RFV, relative feed value 
and in line L2 (1.881\%) as the average of years. Considering the RFV values of the genotypes, the lowest values were obtained from L12 in both years and the highest values were obtained from L24 in the first year, cultivar Karma in the second year and L2 in the average of years.

Similarity levels varied between 0.06-1.90 and there were two main groups (A and B). The first group (A) was composed of 12 triticale lines and the lines in this group (Line2, Line16, Melez 2001, Line14, Alperbey, Line4, Line18, Line12, Line22, Line24, Line6 and Line8) were separated from the second group (B) with a similarity level of 0.78 . Genetically, the Line14 and Alperbey genotypes were found to be $99 \%$ similar with each other. The first group was divided into two sub-groups (A.1 and A.2) with a similarity level of 0.70 . The subgroup A. 1 was composed of Line 8 and Line 6 with a similarity level of 0.53 .

The second group (B) was composed of 13 triticale lines and separated from the first group (A) with a similarity level of 0.55 . The second group was also divided into two sub-groups (B.1 and B.2) with a similarity level of 0.57 . The first sub-group of the second group (B.1) was separated from the second sub-group (B.2) with a similarity level of 0.57 . Only the Line 23 was placed into the B.1 and the lines Line1, Line13, Line3, Line9, Line11, Line19, Line21, Line7, Karma, Mikam 2002, Tatlıcak, Line17 and L23 were placed into the B.2. Within B.2, the lines Line11 and Line19 were the closest lines to each other and they separated from each other with a similarity level of about 0.10 (Figure 1).

Precipitations of the experimental years 20112012 and 2012-2013 were significantly different from each other. Especially the lower precipitations during March and April of the first year and higher precipitations of the second year significantly effected yields and chemical compositions and resulted in significant differences between these parameters. Different plant growth levels in March and April and different responses against water deficits resulted in significant year $\mathrm{x}$ genotype interaction.
Herbage values of the present study were higher than the values reported by Kaplan et al (2011) and similar to the values reported by Lithourgidis et al (2006) and Surmen et al (2011). Hay yields of the current study were similar to the ones reported by Delogu et al (2002); Albayrak et al (2006); Mut et al (2006) and Kaplan et al (2011); and higher than the values of Lithourgidis et al (2006). Such differences in hay yields were mainly due to differences in climate conditions and different responses of genotypes against different conditions. These differences may also result from higher nutrient accumulation levels of early-spiking plants (Delogu et al 2002).

Crude protein content is an essential parameter to evaluate the quality of forages (Caballero et al 1995; Assefa \& Ledin, 2001). Differences in dry matter and crude protein contents usually come from the genetic characteristics of plants but spike-shoot ratio, growing period, temperature and fertilizers are also effective on both parameters (Ball et al 2001). While protein yields of the present study were similar to values reported by Kaplan et al (2011); Lithourgidis et al (2006); Surmen et al (2011) and Mut et al (2006), crude protein ratios were similar

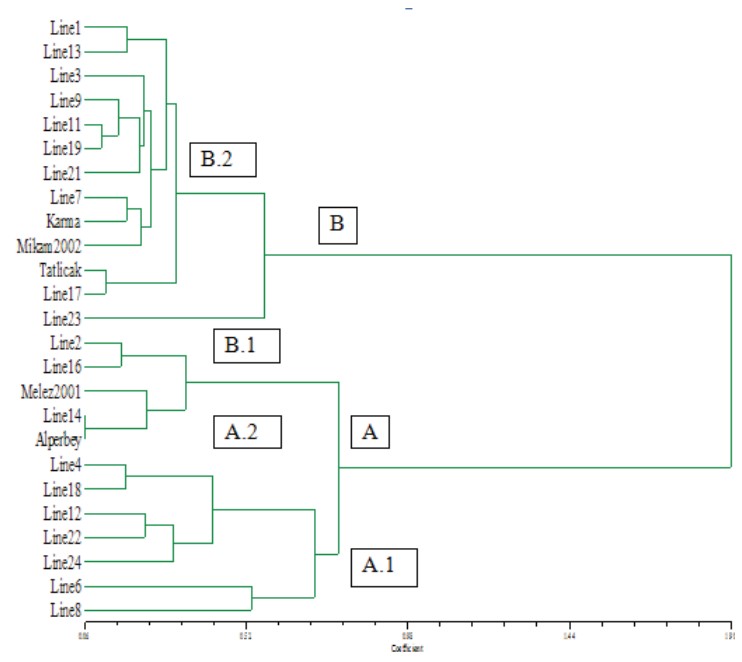

Figure 1- The dendrograms for new triticale lines and cultivars

Şekil 1- Yeni tritikale hat ve çeşitlerine ait dendogram 
to the values of Bilgili et al (2009); Schwarte et al (2005); Delogu et al (2002); Ozdüven et al (2010); Kaplan et al (2011) and Canbolat (2012).

Increase in NDF and ADF contents slow down digestion, physically allow the animal to feel full and limit the feed consumption of animals. Therefore, both parameters are desired at low levels in feed rations (Van Soest 1994; Bozkurt 2011; Canbolat \& Karaman 2009). ADF values of the current study were higher than the ones reported by Lekgari et al (2008); Kaplan et al (2011) and Canbolat (2012) but similar to the ones reported by Lithourgidis et al (2006); Surmen et al (2011) and Özdüven et al (2010). NDF values were higher than the values of Lithourgidis et al (2006); Lekgari et al (2008); Kaplan et al (2011) and Canbolat (2012) but similar to values of Surmen et al (2011); Karadağ \& Buyukburç (2004) and Ozduven et al (2010). Ash content of the present study were similar to values reported by Mut et al (2006) and Canbolat (2012) but higher than the ones reported by Kaplan et al (2011).

Increase in cell wall components (ADF and NDF) limits the digestibility of feeds and consequently negatively affects RFV (Table 5). Compared to a reference value of 100 for alfalfa at full-flowering period, 3 of triticale lines (L2, L8 and L24) were classified as $3^{\text {rd }}$ quality, 16 of them (L1, L3, L4, L9, Melez 2001, L13, L14, Mikam 2002, L16, L18, L19, Alperbey, L21, L22, L23 and Karma) were classified as $4^{\text {th }}$ quality, 6 of them (Tatlicak, L6, L7, L11, L12 and L17) were classified as $5^{\text {th }}$ quality (Rohweder et al 1978). DDM values of the present study were similar but DMI values were lower than the values of Lithourgidis et al (2006). RFV values of the current study were lower than the values reported by Lekgari et al (2008) and Lithourgidis et al (2006) and similar to ones reported by Surmen et al (2011).

\section{Conclusions}

Two-year experiments on hybrid new triticale genotypes revealed that the lines had superior characteristics with regard to investigated parameters over the standard registered cultivars. The line L4 was prominent with herbage yield and the cultivar Melez 2001 was also placed into the highest group. Considering the hay yield, the genotypes L4, L8, L13, L16 and L19 were prominent and had better outcomes than registered cultivars. The line L12 had the highest protein yield and protein ratio. The line L2 was found to be prominent with dry matter intake and RFV and line L24 with regard to only RFV. In general, when the yield and quality parameters are evaluated together, especially the line L4 was found to be promising with its herbage, hay and protein yields per hectare and the line L2 was found to be promising with its relative feed value and dry matter intake. Also, the other lines with prominent different characteristics may also be used as rootstock in further breeding studies.

\section{References}

Albayrak S, Mut Z \& Töngel Ö (2006). Hay and grain yields with some agricultural traits of triticale (XTriticosecale Wittmack) lines. Süleyman Demirel Üniversitesi Ziraat Fakültesi Dergisi 1(1): 13-21

AOAC (1990). Official Method of analysis. 15th. edn. Association of Official Analytical Chemist, Washington, DC. USA

Assefa G \& Ledin I (2001). Effect of variety, soil type and fertilizer on the establishment, growth, forage yield, quality and voluntary intake by cattle of oats and vetches cultivated in pure stand and mixtures. Animal Feed Science and Technology 92: 95-111

Ball D M, Hoveland C S \& Lacefield G D (1996). Forage Quality. In: Southern Forages (2nd edition). 124-132. Potash \& Phosphate Institute and Foundation for Agronomic Research, Norcross, GA

Ball D M, Collins M, Lacefield G D, Martin N P, Mertens D A, Olson K E, Putnam D H, Undersander D J \& Wolf M W (2001). Understanding forage quality. American Farm Bureau Federation Publication 1-01, Park Ridge, IL

Bilgili U, Çifçi E A, Hanoğlu H, Yağdi K \& Açıkgöz E (2009). Yield and quality of triticale forage. Journal of Food Agricultural Environment 7(3-4): 556-560

Bozkurt K A (2011): Determination of relative feed value of some legume hays harvested at flowering stage. Asian Journal of Animal and Veterinary Advances 6: $525-530$ 
Caballero A R, Goicoechea-Oicoechea E L \& HernaizErnaiz P J (1995). Forage yields and quality of common vetch and oat sown at varying seeding ratios and seeding rates of vetch. Field Crops Research 41: 135-140

Canbolat O \& Karaman Ş (2009). Bazı baklagil kaba yemlerinin in vitro gaz üretimi, organik madde sindirimi, nispi yem değeri ve metabolik enerji içeriklerinin karşılaştırılması. Tarım Bilimleri Dergisi-Journal of Agricultural Sciences 15:188-195

Canbolat O (2012). Bazı Buğdaygil Kaba yemlerinin in vitro gaz üretimi, sindirilebilir organik madde, nispi yem değeri ve metabolik enerji içeriklerinin karşılaştırılması. Kafkas Universitesi Veteriner Fakültesi Dergisi 18(4): 571-577

Delogu G, Faecini N, Faccioli P, Reggiani F, Lendini M, Berardo N \& Odoardi M (2002). Dry matter yield and quality evaluation at two phenological stages of forage triticale grown in the Po Valley and Sardinia, Italy. Field Crops Research 74: 207-215

Igne B, Gibson L R, Rippke A \& Hurburg C R (2007). Triticale moisture and protein content prediction by near-infrared pectroscopy. Cereal Chemistry 84: 328330

Kaplan M, Kökten K, Akçura M, Bakoğlu A \& Kavurmac1 Z (2011.) Bazı tritikale çeşit ve hatlarının besin madde kompozisyonunun belirlenmesi. Türkiye $I V$. Tarla Bitkileri Kongresi, Cilt I, Bursa, pp.191-196

Karadag Y \& Buyukburc U (2004). Forage qualities, forage yield and seed yields of some legume triticale mixtures under rainfed conditions. Acta Agric. Scand., Sect. B, Soil and Plant Science 54: 140-148

Koch W D \& Paisley S (2002). Forages of All SeasonsCereal crops: Management for supplemental and emergency forage

Lekgari A L, Baenziger, P S, Vogel K P \& Baltensperger D D (2008). Identifying winter forage triticale ( $\mathrm{x}$ TriticosecaleWittmack) strains for the Central Great Plains. Crop Science 48: 2040-2048

Lithourgidis A S, Vasilakoglou IB, Dhima KV, Dordas CA \& Yiakoulaki MD (2006). Forage yield and quality of common vetch mixtures with oat and triticale in two seeding ratios. Field Crops Research 99: 106-113

McDonald P, Edwards R A, Greenhalgh J F D \& Morgan CA, (1995). Animal nutrition. 5th ed. Pearson Education Ltd., Edinburgh Gate, Harlow Essex, UK

Mut Z, Ayan I \& Mut H (2006). Evaluation of forage yield and quality at two phenological stages of triticale genotypes and other cereals grown under rainfed conditions. Bangladesh, Journal of Botany 35(1): 45-53

Ozduven M L, Kursun Önal Z \& Koç F (2010). The effects of bacterial inoculants and/or enzymes on the fermentation, aerobic stability and in vitro dry and organic matter digestibility characteristics of triticale silages. Kafkas Universitesi Veteriner Fakültesi Dergisi 16 (5): 751-756

Rohweder D A, Barnes R F \& Jorgensen N (1978). Proposed hay grading standards based on laboratory analyses for evaluating quality. Journal of Animal Science 47: 747759 http://jas.fass. org/ cgi/ reprint/47/3/747

SAS Inst (1999). SAS User's Guide: Statistic. Statistical Analysis Systems Institute Inc., Cary, NC

Schwarte A J, Gibson L R, Karlen D L, Liebman M \& Jannink J L (2005). Planting date effects on winter triticale dry matter and nitrogen accumulation. Agronomy Journal 97: 1333- 1341

Sürmen M, Yavuz T, Çankaya N \& Albayrak S (2011). Forage yields and qualities of some triticale (Xtriticosecale Wittmack) genotypes. African Journal of Agricultural Research 6(7): 1686-1691

TSMS (2012). Turkish State Meteorological Service, Statistics of Directorate Kayseri

TSMS (2013). Turkish State Meteorological Service, Statistics of Directorate Kayseri

Uncuer D (2011). Kaba Yem Kaynaklarında Verimliliğin Arttırılması: 1.Tahıl Karışımlarının Biçilerek Yıllık Yem Kaynağı Olarak Kullanımı. Kocatepe Tarımsal Araştırma Enstitüsü Müdürlügüu, http://web.ttnet.com. tr/kocatepetae/proje\%20on\%20teklifi.htm

Van Soest P J (1963). The use of detergents in the analysis of fibre feeds. II. A rapid method for the determination of fiber and lignin. Journal of the Association of Official Analytical Chemists 46:829-835

Van Soest P J \& Wine R H (1967). The use of detergents in the analysis of fibrous feeds. IV. Determination of plant cell wall constituents. Journal of the Association of Official Analytical Chemists 50:50-55

Van Soest P J (1982). Nutritional ecology of the ruminant: Ruminant metabolism, nutritional strategies, the cellulolytic fermentation and the chemistry of forages and plant fibers. O \&B Books Publisher, Corvallis, OR., USA

Van Soest P J (1994): Nutritional ecology of the ruminant (2nd Ed.). Cornell University Press, Ithaca, NY, pp. 528 